\title{
Nature and sedimentation of suspended particulate matter during density stratification in shallow coastal waters (Gulf of Trieste, northern Adriatic)
}

\author{
Nives Posedel, Jadran Faganeli \\ Marine Biological Station Piran, JLA 65, YU-66330 Piran, Yugoslavia
}

\begin{abstract}
Suspended particulate matter in the Gulf of Trieste (northern Adriatic) during seawater density stratification in summertime consists of about $5 \%$ total hydrolyzable carbohydrates, $2 \%$ proteins and $1.0 \%$ lipids. The bulk of particulate organic matter (POM) remains uncharacterized and is probably composed mainly of terrigenous refractory material, evidenced by more negative total POM $\delta^{13} \mathrm{C}$ values (ca $-24.5 \%$ ) and a somewhat higher $\mathrm{C} / \mathrm{N}$ atomic ratio (6.5). The composition of diatomaceous macroaggregations observed in the whole northern Adriatic in the summers of 1988 and 1989 containing 12 to $34 \%$ total hydrolyzable carbohydrates, 0.3 to $1.4 \%$ proteins, ca $0.08 \%$ lipids, and a high $\mathrm{C} / \mathrm{N}$ ratio) differed from that of summer POM. The predominance of glucose (ca $60 \%$ of total hydrolyzable carbohydrates), and $\delta^{13} \mathrm{C}$ values typical of cultured diatoms $(-17$ to $-19 \%$ ), suggested that the bulk of macroaggregate organic matter was composed of algal structural products, possibly glucans. Amino acid composition was dominated by glycine, aspartic acid, alanine and glutamic acid and was similar to common summer POM. Sedimented POM, measured by moored sediment traps, was depleted of proteins and water-soluble carbohydrates by 80 to $85 \%$ and of lipids by $74 \%$ with respect to summer POM composition. Rapid sedimentation of macroaggregates in mid-August 1989 scavenged the POM from the water column during disruption of density stratification. Sedimentation was reflected in higher total sedimented organic matter (ca $25 \%$ ) but lower protein, water-soluble carbohydrate and lipid contents.
\end{abstract}

\section{INTRODUCTION}

Suspended particulate matter (SPM) in seawater is composed of mineral and organic fractions (Sackett 1978). The organic fraction or particulate organic matter (POM) is predominantly composed of detritus, except during phytoplankton blooms when living organic matter predominates.

POM in ocean waters originates almost entirely from biological (mostly phytoplankton) production, while in coastal waters terrigenous input could be an important source of POM (Degens \& Ittekkot 1985). A somewhat curious type of POM in seawater is represented by large organic macroaggregates between $1 \mathrm{~mm}$ and several meters in size (Alldredge 1979), which are thought to be the products of decomposition of phytoand zooplankters (Smetacek 1985, Alldredge \& Gotschalk 1989).
Macroaggregates represent an important site of accumulation and degradation of organic matter in the seawater column, contributing to the patchiness of POM distribution in seawater. The regular occurrence of macroaggregates in summertime in the Mediterranean (Heusner et al. 1987) and in the northern Adriatic (Herndl \& Peduzzi 1988) is well documented. In summer 1988 and 1989 great quantities of macroaggregates appeared in the whole northern Adriatic (Brambati et al. 1988, Degobbis 1989), due to diatomaceous blooms (Fanuko \& Turk 1990); these macroaggregates were composed of entrapped phytoplankters, microzooplankters, bacteria and mineral particles (Stachowitsch et al. 1990).

POM, produced in the euphotic part of the water column, degrades into nitrogen- and phosphorusdepleted organic matter when sedimenting, due to the lower energies of $\mathrm{C}-\mathrm{N}$ and $\mathrm{C}-\mathrm{P}$ bonds in comparison to 
C-C and C-H bonds (Toth \& Lerman 1977). This degradation also leads to the formation of refractory organic compounds resistant to subsequent microbial degradation. Many transformations of POM occurring in the water column are similar to those in recent sediment (Lee \& Wakeham 1989, Wakeham \& Lee 1989). Only larger particles such as faecal pellets (Small et al. 1987), phytodetritus (Billett et al. 1983), or macroaggregates (Fowler \& Knauer 1986, Alldredge \& Silver 1988) could reach the sediment with unaltered or relatively littlealtered chemical composition. Smaller particles represent food for zooplankters and are thus involved in rapid transport by zooplankton vertical migration, or could be incorporated into larger faecal pellets through zooplankton coprophagy (Turner \& Ferrante 1979).

In shallow coastal waters, where biological production and degradation occur together throughout the water column, most of the POM degradation and mineralization processes occur at the sediment-water interface. These benthic processes, consuming dissolved oxygen in bottom water layers, are important sources of nutrients for benthic primary production. Benthic organic matter also contributes to sedimented POM by resuspension and hence the net distinction between pelagic and benthic origins is usually difficult. Analyses of biochemical markers (Cowie \& Hedges 1984, Ittekkot et al. 1984), and contents of stable isotopes of C and N (Fry \& Sherr 1984, Altabet 1989) are currently applied with some success, though not without uncertainties, including multiple sources of organic matter and isotopic changes during decomposition (Fry \& Sherr 1984).
The aim of the present work was to study the origin and variations in chemical composition of POM in the water column of the Gulf of Trieste (northern Adriatic) during the period of density stratification, in terms of particulate organic carbon (POC), particulate nitrogen (PN), particulate proteins, amino acids, carbohydrates and lipids. A comparison was made with the annual variations of POM composition in this area in previous years (1980 to 1983), which apparently were not affected by any planktonic blooms. Special attention was paid to determining the composition, origin, and transformation during sedimentation of macroaggregates produced by diatomaceaous blooms in the summers of 1988 and 1989.

\section{MATERIALS AND METHODS}

Samples. Samples for analysis of POM were taken weekly at a fixed sampling point (MA) located in the SE part of the Gulf of Trieste (Fig. 1) at a depth of $17 \mathrm{~m}$. from July to September 1989, during thermal and density stratification in the water column (Fig. 2). Samples for POM, POC, PON, particulate proteins, carbohydrates and lipids were collected from the surface $(0.3 \mathrm{~m})$ and bottom $(16 \mathrm{~m})$ layers using 51 Niskin samplers. During the period 1980 to 1983 samples were collected monthly at the sampling points MA and $\mathrm{K}-1$ (Fig. 1) at depths of $0.5,5,10,16 \mathrm{~m}$. Macroaggregates forming a 'creamy surface layer' (Stachowitsch et al. 1990) were collected in the Bay of Piran (Fig. 1) in July 1988 and July 1989 at the sea

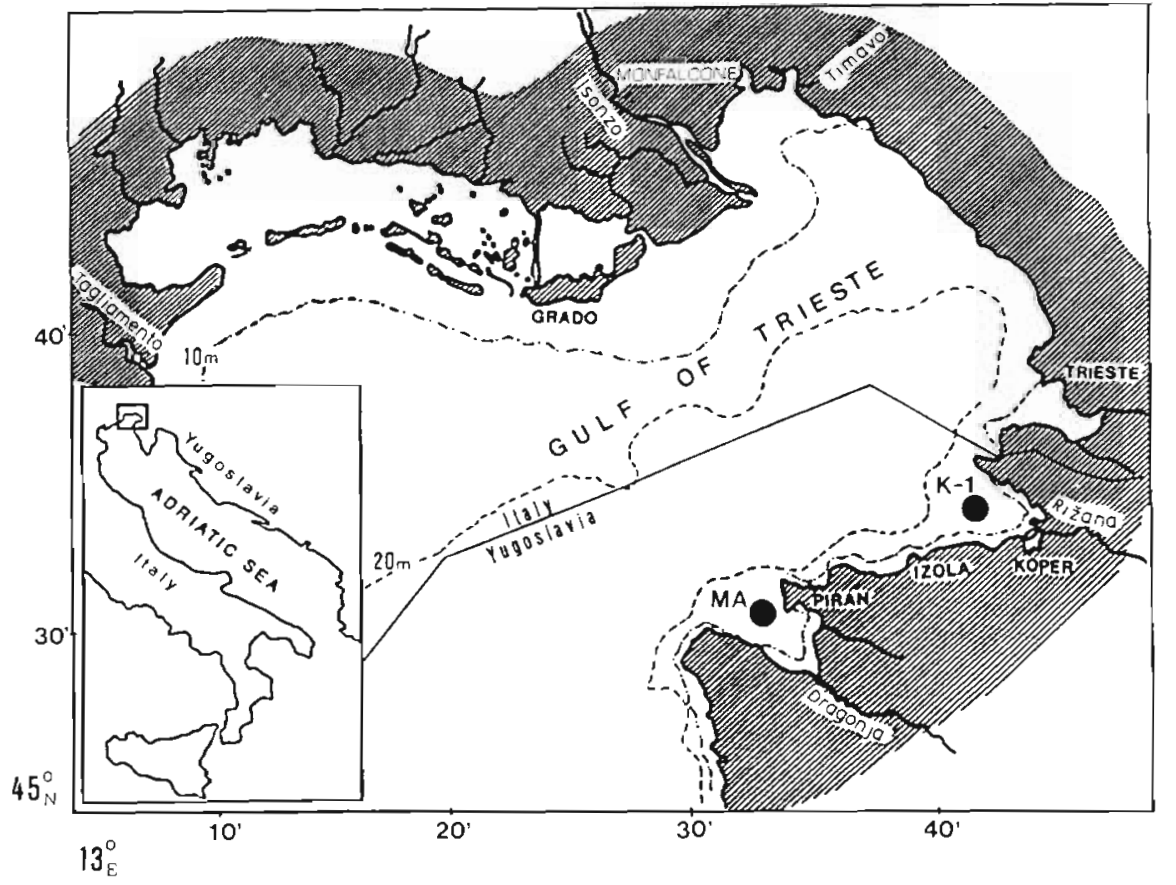

Fig. 1. Location of sampling points $\mathrm{K}-1$ and $\mathrm{MA}$ in the Gulf of Trieste (northem Adriatic) 
Fig. 2. Vertical profiles of temperature $\left({ }^{\circ} \mathrm{C}\right)$, salinity $(\%)$ and density in the water column in the southern part of the Gulf of Trieste on (A) 5 July, (B) 25 July, (C) 24 August and (D) 6 September 1989. Data from the Marine Biological Station Piran
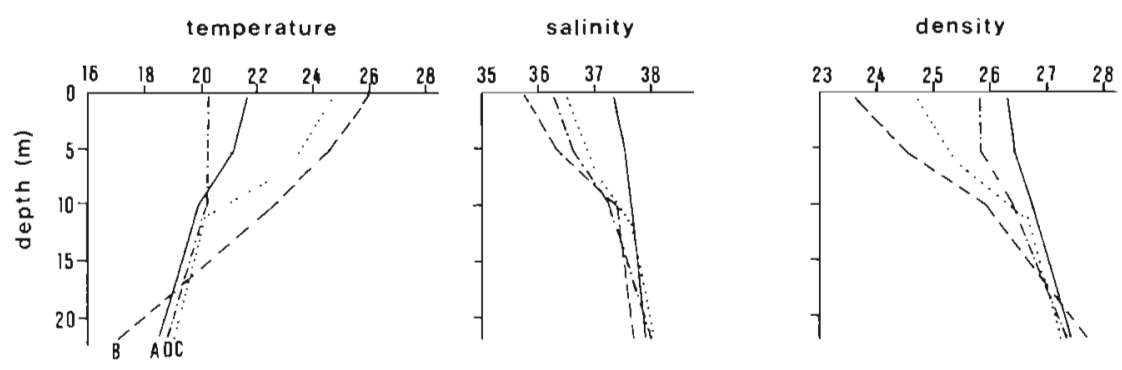

surface and bottom by SCUBA, using polyethylene bottles.

The sedimentation rate of POM was measured from July to September 1989 at point MA (Fig. 1) with a moored sediment trap, similar to that described by Blomqvist \& Kofoed (1981). The trap was situated ca $1 \mathrm{~m}$ above the bottom to reduce the influence of sediment resuspension. The trap was designed to collect 4 samples simultaneously and consisted of 4 plastic cylinders, each $80 \mathrm{~cm}^{2}$ in area. The height/width ratio of the cylinders was ca 5. The amount of POM was measured over a period of $24 \mathrm{~h}$ once a week.

Samples of particulate matter (21), macroaggregates (1) and sedimented particulate matter were filtered through Whatman GF/F glass-fiber filters pre-ignited for $3 \mathrm{~h}$ at $480^{\circ} \mathrm{C}$ to eliminate organic contaminants. The material collected on the filters was rinsed several times with distilled water to remove salts. All samples were dried at $60^{\circ} \mathrm{C}$ overnight and weighed. Dried samples were used for analysis of $\mathrm{C}, \mathrm{H}$, and $\mathrm{N}$ content, ${ }^{13} \mathrm{C}$ content of organic matter, and protein, amino acid, total and water-soluble carbohydrate, and lipid contents.

Analyses. Total particulate and sedimented particulate matter was determined gravimetrically, and the organic fraction was measured as the difference between the total and that remaining after combustion at $500^{\circ} \mathrm{C}$. C, $\mathrm{H}$ and $\mathrm{N}$ content was determined with a commercial CHN analyzer (Coleman). Analysis of ${ }^{13} \mathrm{C}$ isotopic fractionation in the $\mathrm{CO}_{2}$ produced was performed with a Varian MAT 250 mass spectrometer and the results expressed as per mil (\%) deviations from the ${ }^{13} \mathrm{C} /{ }^{12} \mathrm{C}$ ratio of the Chicago $\mathrm{PDB}$ standard $\left(\delta^{13} \mathrm{C}\right)$.

Protein contents in samples were determined in aqueous homogenates (Packard \& Dortch 1975) colorimetrically, using a slightly modified Coomassie Brilliant Blue protein assay (Bio Rad or Pierce, USA) method of Setchell (1981) with casein as a standard (Mayer et al. 1986). Casein seems to be an appropriate standard for this protein assay in plankton generally. The commonly used bovine serum albumin (BSA) standard in the protein assay with the Coomassie Brilliant Blue method (Kochert 1978) gives low results in plank- ton analyses, since the response of various proteins is not uniform. Bovine $\gamma$-globulin, ovalbumin and casein give approximately identical results (Setchell 1981, Faganeli et al. 1989). The Coomassie Brilliant Blue protein assay (Pierce reagent) was tested for interferences from other natural polymeric products in the marine environment, i.e. humates and lignin. The aqueous solutions of wood ligninsulphonate and purified fulvic acid, isolated from coastal marine sediment (west coast of Sweden), gave no response in the range 5 to $800 \mu \mathrm{g} \mathrm{ml}^{-1}$. A purified humic acid, isolated from the same marine environment, exhibited an absorbance of about $1 / 3$ that of casein in the same concentration range. It seems possible that the humic acid tested consists of some larger polypeptide residues adsorbed or bonded onto the structure of humic acid (Domagalski et al. 1989).

Amino acid composition was determined by hydrolysis of samples in $6 \mathrm{~N} \mathrm{HCl}$ in sealed evacuated ampoules at $110^{\circ} \mathrm{C}$ for $20 \mathrm{~h}$ and by subsequent analysis using a Beckman $118 \mathrm{CL}$ amino acid analyzer. Total carbohydrate contents were determined colorimetrically using the phenol-sulphuric acid method of Dubois et al. (1956) with D-glucose as a standard after hydrolysis of samples in sealed ampoules in $1 \mathrm{M} \mathrm{H}_{2} \mathrm{SO}_{4}$ at $100^{\circ} \mathrm{C}$ for $4 \mathrm{~h}$ (Mopper 1977). Monosaccharides were determined by thin-layer chromatography (TLC) on Kieselgel 60 WRF $254 \mathrm{~S}$ plates (Merck) using a mobile phase composed of acetonitrile: phosphate buffer $(\mathrm{pH}=$ 5.5) : methanol in the proportions 179:39:0.2. Detection of monosaccharides was performed visually using a mixture of diphenylamine, aniline and phosphoric acid (20\% in methanol), comparing with standards.

Water-soluble carbohydrate contents of samples were analyzed in water homogenates (Packard \& Dortch 1975) using the phenol-sulphuric acid method of Dubois et al. (1956) with D-glucose as a standard. Lipid content was determined by extraction with a mixture of chloroform and methanol $(2: 1)$ and subsequent colorimetric detection using the sulphophospho-vanillin method of Zöllner \& Kirsch (1962) and cholesterol as a standard.

The composition of the mineral fraction was determined by $\mathrm{X}$-ray diffraction analysis. 


\section{RESULTS}

\section{Composition and sedimentation of SPM}

Temporal variations in the composition of POM from July to September 1989 are depicted in Fig. 3. Concentrations of protein varied in the range 20 to $40 \mathrm{\mu g} \mathrm{l}^{-1}$, these of water-soluble carbohydrates between 10 and $40 \mu \mathrm{g} \mathrm{l}^{-1}$ and of lipids between 0 and $200 \mu \mathrm{g} \mathrm{l}^{-1}$ in the surface and bottom layers. The lowest concentrations of all particulate constituents were detected in midAugust 1989 in both layers. The temporal variations in both layers were similar, except that higher concentrations were observed at the bottom. The sum of analyzed constituents varied widely and represented between 2 and $28 \%$ of the total particulate matter and between 6 and $84 \%$ of POM (Fig. 4)

Sedimentation rates of particulate matter, POM, particulate proteins, water-soluble carbohydrates and lipids ranged from 8.6 to $106 \mathrm{~g}, 3$ to $12 \mathrm{~g}, 50$ to $540 \mathrm{mg}$, 40 to $170 \mathrm{mg}$ and 0 to $420 \mathrm{mg} \mathrm{m}^{-2} \mathrm{~d}^{-1}$, respectively (Fig. 3). The temporal variations in sedimentation rates of particulate components during collection followed the variations in concentration of particulate substances in the water column. The highest sedimentation rate of POM but the lowest of particulate proteins, water-soluble carbohydrates and lipids was observed in mid-August 1989, in parallel with the lowest concentrations of these particulate substances in the water column. The content of sedimented POM decreased during the following $2 \mathrm{wk}$ with increasing content of other sedimented particulate substances.

Lipids, proteins and water-soluble carbohydrates represented respectively between 0 and 1.3,0.20 and 1.85 , and 0.08 and $0.40 \%$ of sedimented matter, and together represented about $10 \%$ of the total sedimented POM and between 1.5 and $4.5 \%$ of the total sedimented matter (Fig. 5). All of the organic constituents analyzed comprised only ca $25 \%$ of the sedimented POM and $6.5 \%$ of total sedimented matter The major part ( 75 to $85 \%$ ) of the total sedimented matter was composed of an inorganic fraction with the following minerals: calcite (28\%), illite (21\%), quartz $(19 \%)$, chlorite $(15 \%)$, plagioclase $(6 \%)$, dolomite $(6 \%)$, microcline $(4 \%)$ and pyrite $(2 \%)$ (Fig. 5$)$.

Concentrations of the particulate constituents between 1980 and 1983 (Fig. 6A) exhibited intensive temporal fluctuations without statistically significant correlation (paired t-test, $\mathrm{p}<0.01$ ) between particulate constituents or between them and phytoplankton biomass (based on chlorophyll a concentration). The differences between sampling points and depths were not significant ( $t$-test, $p<0.01)$. However, the total particulate carbohydrate concentration maxima observed in the period May-June coincided with low nitrate in seawater (Fig. 6B)

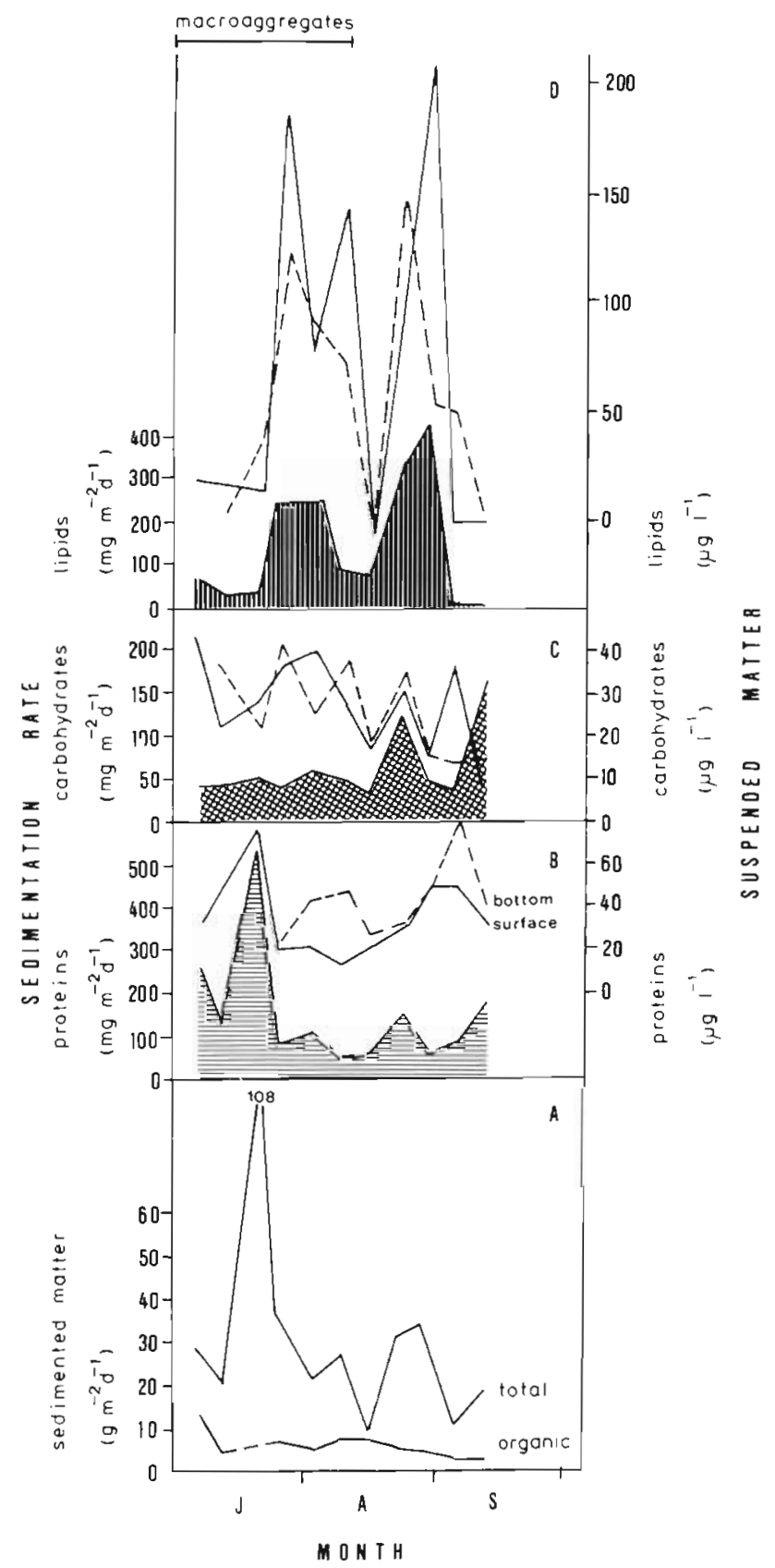

Fig. 3. (A) Sedimentation rate of total and organic suspended matter; and sedimentation rate and concentration variations of (B) particulate proteins, (C) water-soluble partıculate carbohydrates, and (D) particulate lipids, in the surface $10.5 \mathrm{~m}$; continuous line) and bottom (15 m; dashed line) layers at sampling point MA from July to September 1989. Horizontal line at top indicates occurrence of macroaggregates

\section{Composition of macroaggregates}

The chemical and ${ }^{13} \mathrm{C}$ isotopic composition of macroaggregates in July 1988 and July 1989 is reported in 


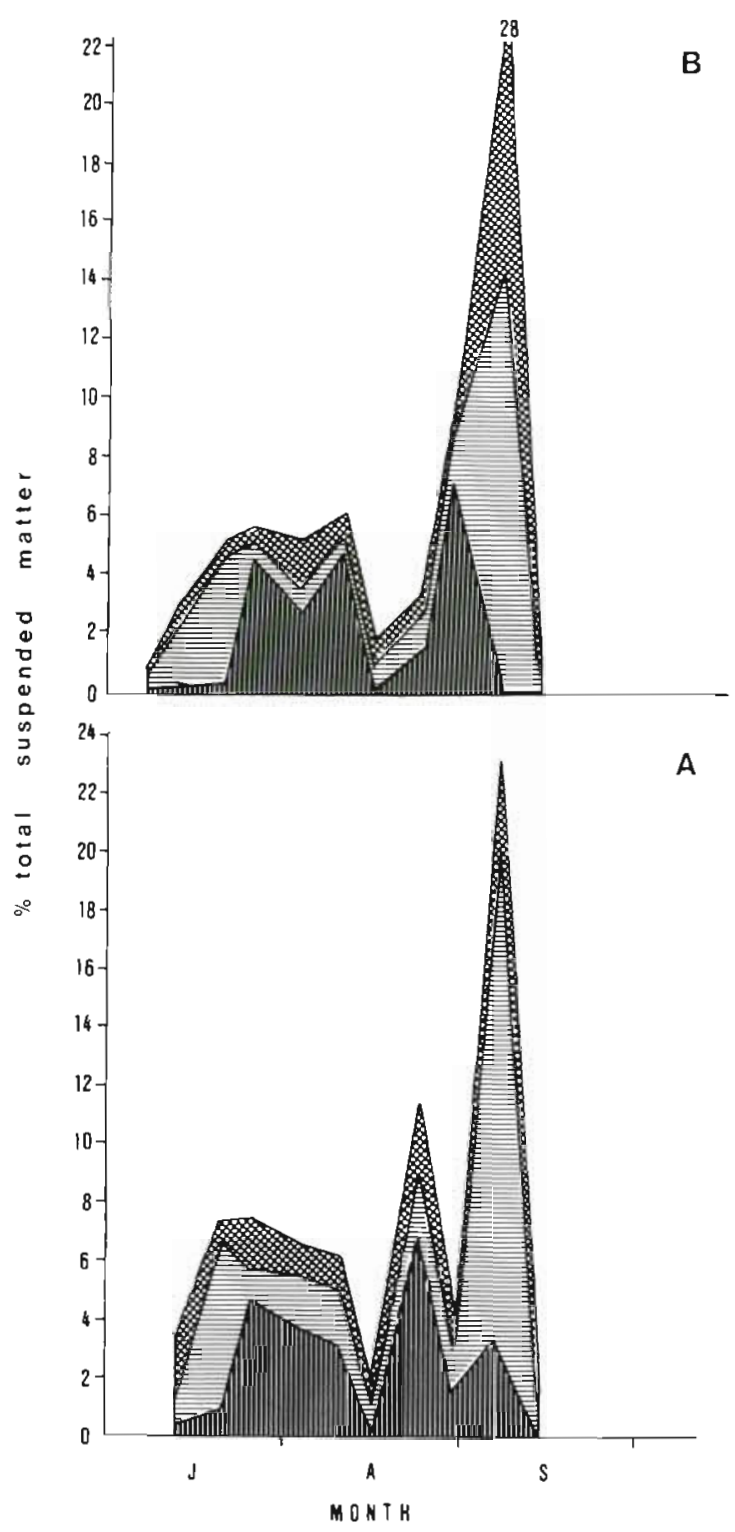

Fig. 4. Variation in composition of suspended matter in the (A) bottom and $(B)$ surface layers at sampling point MA from July to September 1989. Patterns for components in Fig. 3

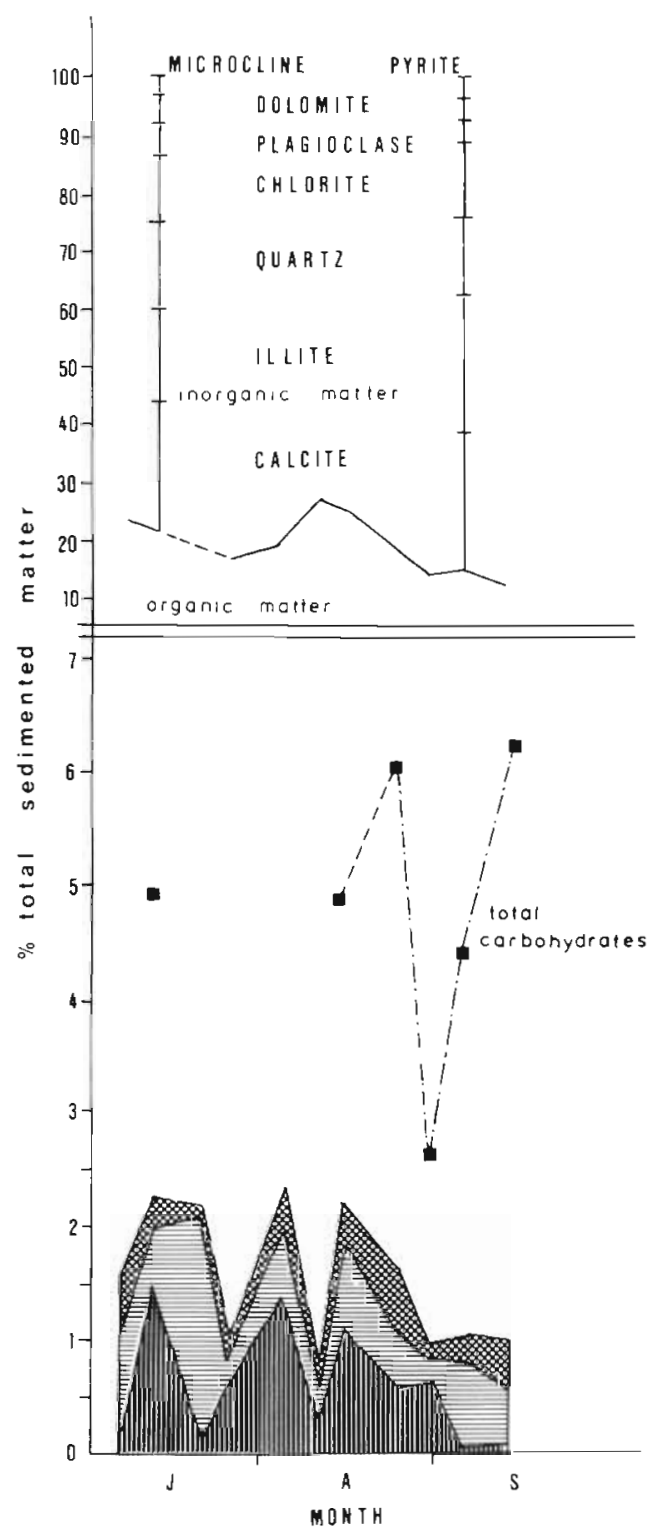

Fig. 5. Variations in composition of sedimented matter at sampling point MA from July to September 1989. Patterns for components as in Fig. 3
Table 1. Content of organic matter varied between 35 and $57 \%$ and that of organic C between 10 and $25 \%$, with an organic matter:organic $C$ ratio between 2 and 3.6. The total $N$ content of surface macroaggregates was low, with a higher value (3.4\%) in sedimented macroaggregates in July 1988. The C/N atomic ratio of surface macroaggregates was high (15 to 29 ), but a lower $\mathrm{C} / \mathrm{N}$ ratio was found in sedimented macroaggregates.

Total carbohydrates were the major component com- prising total matter (11.6 to $33.5 \%$ ), and glucose comprised up to $60 \%$ of the total carbohydrates. On the other hand, water-soluble carbohydrate contents ranged between 11 and $15 \%$ of total hydrolyzable carbohydrates. Protein content was low, comprising only about $68 \%$ of total hydrolyzable amino acid. The amino acid spectrum of macroaggregates (Table 2) was similar to that of typical summer POM in the Gulf of Trieste. The most abundant amino acids were glycine, 


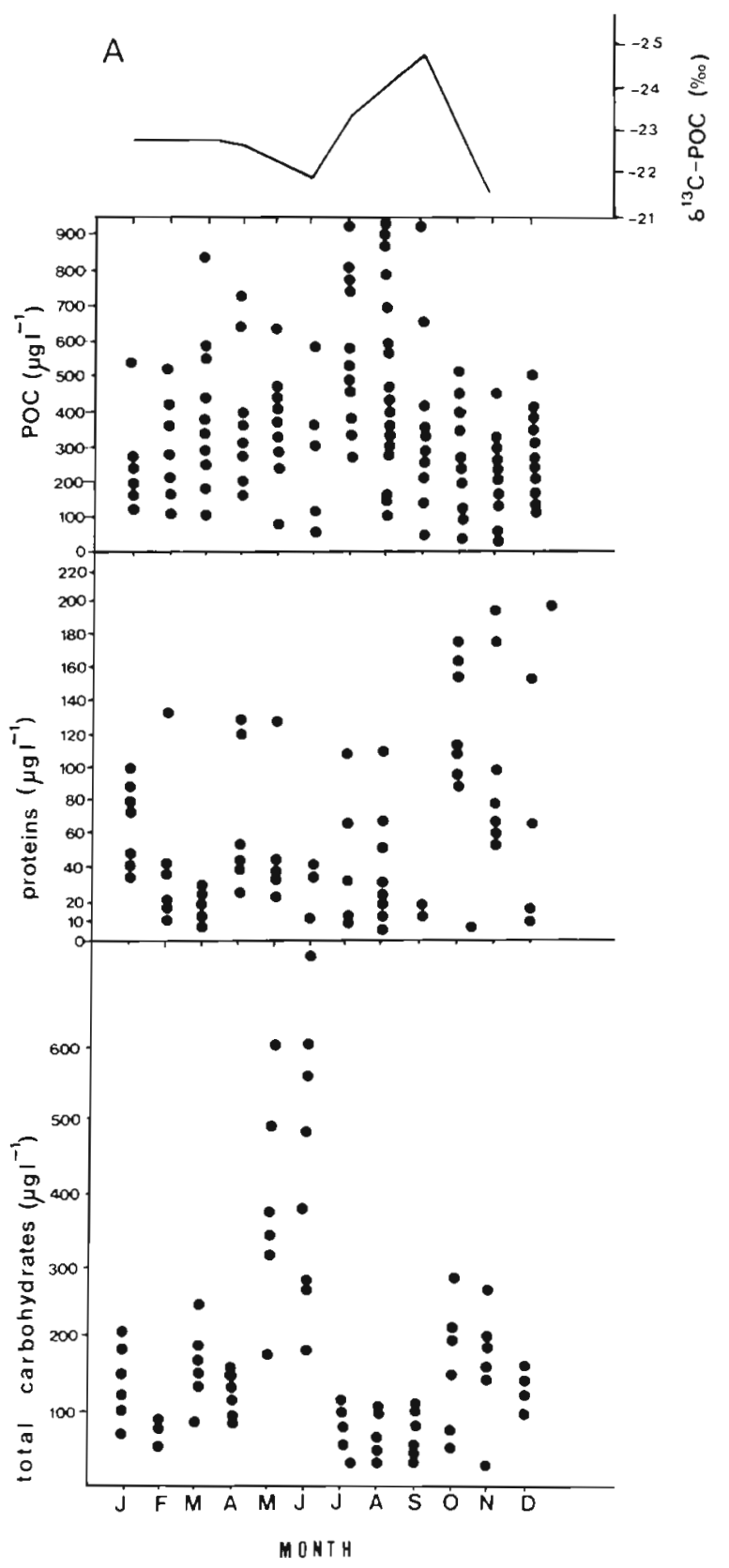

aspartic acid, alanine and glutamic acid in both materials. The sum of all analyzed constituents accounted for 23 to $100 \%$ of the total organic matter content.

\section{DISCUSSION}

\section{Composition of SPM}

The annual variation in particulate substances was apparently unaffected by the appearance of macroaggregates, displaying little synchronization with phy-

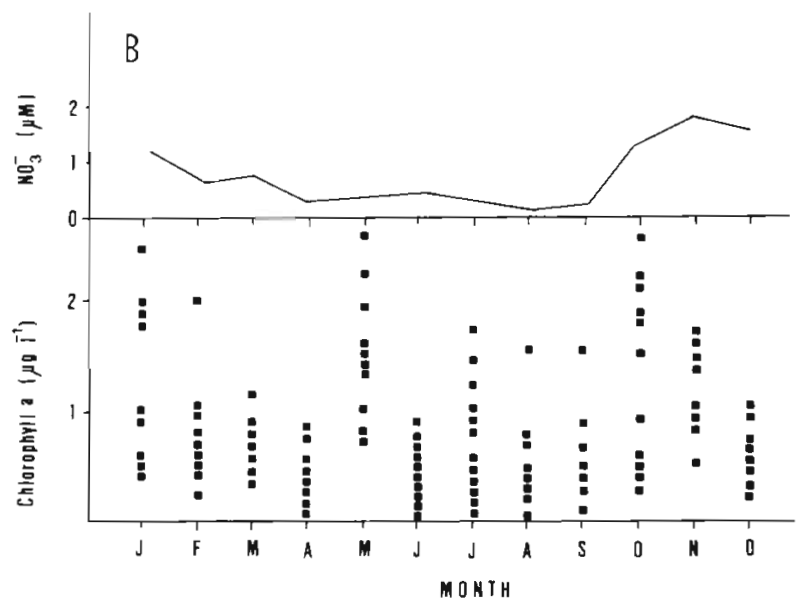

Fig. 6. (A) Variations in surface $(0.5 \mathrm{~m}) \mathrm{\delta}^{13} \mathrm{C}-\mathrm{POC}$ values at sampling point $\mathrm{MA}$, and in particulate organic carbon ( $P O C$ ), particulate proteins and particulate total carbohydrates at depths of $0.5,5,10$ and $15 \mathrm{~m}$ at sampling points $\mathrm{K}-1$ and $\mathrm{MA}$ from 1980 to 1983 (see 'Results' for discussion). (B) Variations in concentration of phytoplankton biomass (from the chlorophyll a concentrations; courtesy of N. Fanuko) at depths of $0.5,5.10$ and $15 \mathrm{~m}$, and mean water-column concentrations of $\mathrm{NO}_{3}$ at sampling points $\mathrm{K}-1$ and MA, from 1980 to 1983. $\mathrm{NO}_{3}$ concentration data are from the Marine Biological Station Piran (see explanation in text)

toplankton biomass (based on chlorophyll a) and a marked occurrence of high total particulate carbohydrate content in the period May-June. This phenomenon coincided with lower seawater nitrate concentrations, similar to the observations reported by Haug et al. (1973), indicating the prevalent synthesis of carbohydrates in phytoplankton during depletion of nitrate in the surrounding water. The high summer POC concentrations were most likely a result of a higher contribution of allochthonous $\mathrm{POC}$, as illustrated by more negative $\delta^{13} \mathrm{C}$-POC values (Faganeli et al. 1988). The scattered PN data on the POC vs PN plot 
Table 1. Composition of macroaggregates in the SE part of the Gulf of Triste ( $\%$ of dry weight)

\begin{tabular}{|c|c|c|c|}
\hline Component & 1989 (surface) & 1988 (surface) & 1988 (bottom) \\
\hline Organic matter & 57.3 & 35.3 & 47.4 \\
\hline C & 17.73 & 9.77 & 24.94 \\
\hline $\mathrm{H}$ & 2.12 & 2.08 & 3.85 \\
\hline $\mathrm{N}$ & 0.72 & 0.84 & 337 \\
\hline $\mathrm{C} / \mathrm{N}$ (atomic) & 28.7 & 15.3 & 8.6 \\
\hline Total carbohydrates & 11.48 & 33.53 & - \\
\hline Water-soluble carbohydrates & 1.23 & 1.89 & - \\
\hline Proteins & 0.34 & 1.36 & - \\
\hline Total amino acids & 1.57 & 2.19 & - \\
\hline Lipids & 0.09 & 0.07 & - \\
\hline Carbohydrates + total amino acids + lipids & 13.1 & 35.8 & - \\
\hline$\delta^{13} \mathrm{C}(\%)$ & -18.9 & -17.0 & -21.3 \\
\hline
\end{tabular}

Table 2. Amino acid composition ( $\mathrm{mol} \%$ ) of macroaggregates and suspended matter in the SW Gulf of Trieste

\begin{tabular}{|c|c|c|c|}
\hline \multirow[t]{2}{*}{ Amino acid } & \multicolumn{2}{|c|}{ Macroaggregates } & \multirow{2}{*}{$\begin{array}{c}\text { Suspended matter } \\
1983\end{array}$} \\
\hline & 1988 & 1989 & \\
\hline Ala & 12.0 & 11.2 & 10.7 \\
\hline Arg & 1.4 & 3.4 & 3.5 \\
\hline Asp & 13.9 & 9.8 & 13.7 \\
\hline Glu & 10.3 & 12.1 & 12.5 \\
\hline Gly & 17.2 & 11.2 & 12.0 \\
\hline His & 0.8 & 1.9 & 1.9 \\
\hline Ile & 4.2 & 6.4 & 4.0 \\
\hline Leu & 6.0 & 8.8 & 6.9 \\
\hline Lys & 3.1 & 6.4 & 5.1 \\
\hline Met & 0 & 0 & Traces \\
\hline Phe & 3.0 & 4.6 & 4.0 \\
\hline Pro & 8.2 & - & 3.8 \\
\hline Ser & 6.7 & 6.3 & 8.3 \\
\hline Thr & 5.1 & 8.2 & 6.7 \\
\hline Tyr & 1.0 & 1.4 & 0 \\
\hline Val & 6.3 & 8.3 & 6.9 \\
\hline
\end{tabular}

$\left(r^{2}=0.64, p<0.01 ;\right.$ Fig. 7$)$ are probably a consequence of the fact that a substantial part of $\mathrm{PN}$ consists of dissolved $\mathrm{N}$ adsorbed onto particles or inorganically bonded, since the $\mathrm{POC}$ vs $\mathrm{PN}$ regression line (POC = $3.3 \mathrm{PN}+114.2 ; \mathrm{n}=150$ ) indicates that not all $\mathrm{N}$ is organically bound. Up to $20 \%$ of total $N$ in surficial sediment of the Gulf of Trieste was found to consist of inorganic $N$, i.e. the sum of fixed ammonium and exchangeable ammonium, nitrate and nitrite ions (Faganeli et al. 1991). This statement is supported by the data on particulate protein and amino acids, consisting of a yearly average of ca 16 and $30 \%$, respectively, of PN in the Gulf (Faganeli 1989). This also in part explains the unusually low mean $C / N$ ratio of particulate matter in the Gulf.

Floristic analysis of macroaggregates showed that they were composed of live and dead diatoms, especially of the genus Nitzschia, as well as of microflagel- lates and bacteria (Fanuko \& Turk 1990, Stachowitsch et al. 1990). Analysis of chemical composition revealed that carbohydrates were the principal constituent of macroaggregates, with glucose being the most abundant monosaccharide in acid hydrolyzates, and a low content of the water-soluble carbohydrates. This suggests that the principal components were structural glucans of the diatom cell wall, since storage polysaccharides are water-soluble (Handa \& Yanagi 1969). The carbohydrates of diatoms are generally divided into storage (reserve) polysaccharides principally composed of glucose (Handa \& Yanagi 1969, Haug \& Myklestad 1976), structural cell-wall polysaccharides consisting of rhamnose, fucose, ribose, arabinose, xylose, mannose, galactose and glucose (Handa \& Yanagi 1969, Haug \& Myklestad 1976) bonded with amino acids to silicate in frustula (Hecky et al. 1973), and extracellular polysaccharides composed principally of rhamnose, fucose and galactose, with a minor contribution of xylose, mannose and galactose (Haug \& Myklestad 1976, Percival et al. 1980). The monosaccharide composition of diatomaceous mucus, according to Ittekkot et al. (1982). is similar to that of the frustula. In our sample pretreatment these monosaccharides were probably lost by vacuum filtration, as reported by Ittekkot et al. (1984) and Liebezeit (1987). The high reserve polysaccharide content in diatom spores was suggested by Liebezeit (1987) to be important to diatom survival strategy (Smetacek 1985) in 3 ways: the increasing amount of reserve polysaccharide, probably glucans, increases the density of the spore and thus the sinking velocity, the high content of reserve polysaccharides serves as an energy store and prolongs survival time, and the degradation of reserve glucans decreases cell density and thus facilitates optimal growth conditions.

Our statement that the majority of carbohydrates originates from structural polysaccharides does not agree with the observation of Liebezeit (1987) but does, on the other hand, agree with that of Tanoue \& Handa 


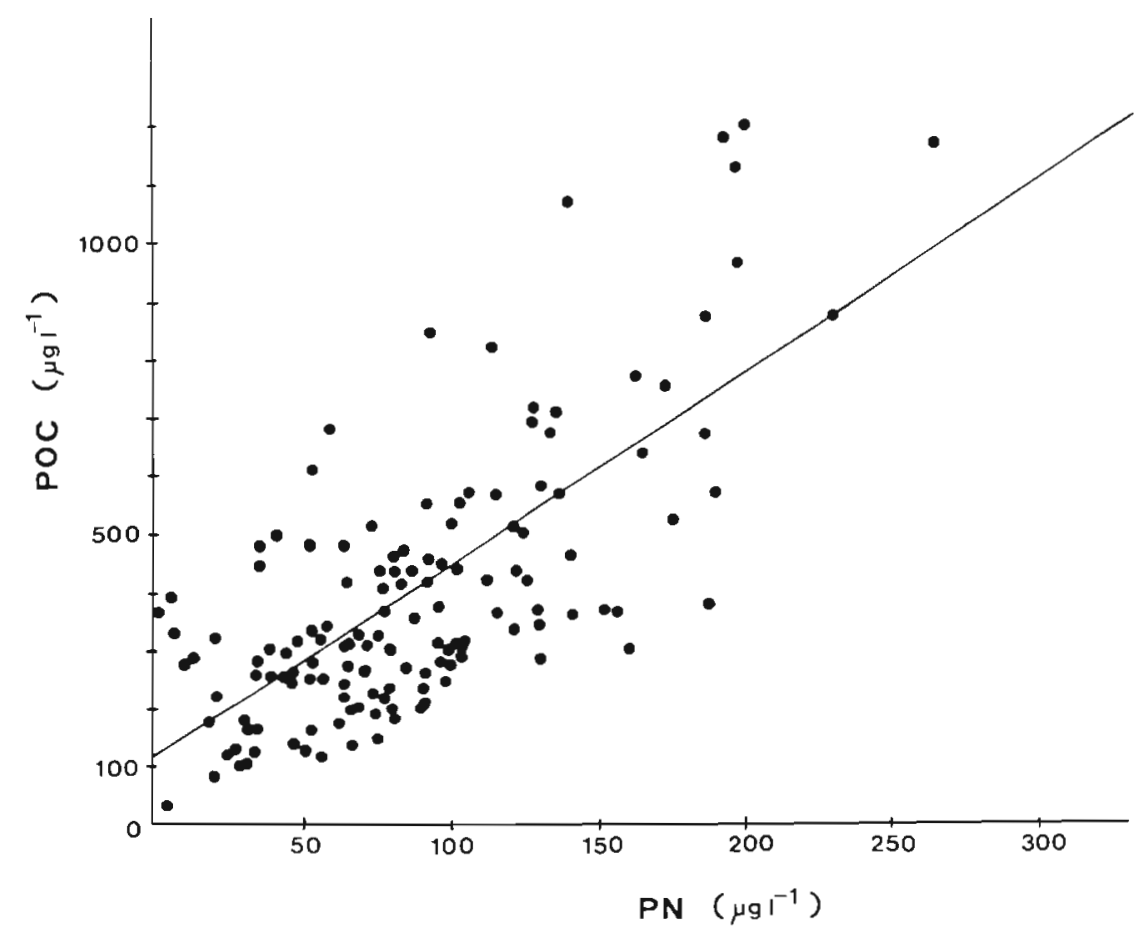

Fig. 7. Relationship between particulate organic carbon (POC) and particulate nitrogen $(P N)$ at sampling points $K-1$ and $M A$ in the southern part of the Gulf of Trieste from 1980 to 1983. The regression line is described by the equation: $\mathrm{POC}=3.3 \mathrm{PN}+$ $114.2 ; r^{2}=0.64, n=150$
(1987). Thus, the ratio of glucose to galactose, proposed as an index of predominance of storage or structural polysaccharides in diatoms (Ittekkot et al. 1982), seems not to be applicable in this case.

The amino acid composition of macroaggregates suggests that they were mostly not bonded to the silicate frustula, since in general it shows no marked enrichment of glycine, serine and threonine and a decrease of acidic, sulphur-containing and aromatic acids (Hecky et al. 1973) relative to the amino acid composition of summer POM (Table 2). Low lipid concentrations of macroaggregates were also reported by Degobbis (1989) along the western. Istrian coast.

The source of macroaggregates could be deduced using their $\delta^{13} \mathrm{C}$ values and their position on a graph of the $\delta{ }^{13} \mathrm{C}$ values vs $\mathrm{C} / \mathrm{N}$ ratios of different classes of organic matter in the Gulf of Trieste (Faganeli et al. 1988). The $\delta^{13} \mathrm{C}$ values of surface macroaggregates were similar to those of batch-cultured diatoms (Chaetoceros affinis, Nitzschia closterium), isolated from the Gulf of Trieste, in the stationary phase of growth (Faganeli et al. 1989). The $\mathrm{C} / \mathrm{N}$ ratio was high due to the strong predominance of carbohydrates and depletion of organic nitrogen compounds. Thus, these macroaggregates could be classified as predominantly of pelagic origin.

The composition of summer POM in the Gulf of Trieste differed from that of macroaggregates. The summer POM in the surface and bottom layers contained higher quantities of proteins, lipids and watersoluble carbohydrates; this is in accordance with the observation of Alldredge (1979) for the waters of southern California. A comparison of the mean $\mathrm{C}$ and $\mathrm{N}$ contents of POM (Faganeli 1989) with those of macroaggregates revealed higher $\mathrm{C}$ and lower $\mathrm{N}$ in the latter, with a consequently higher $\mathrm{C} / \mathrm{N}$ ratio. This higher $\mathrm{C} / \mathrm{N}$ ratio is partially attributed to the intense degradation processes occurring within the dense macroaggregates (Alldredge 1989). The $\delta^{13} \mathrm{C}$ values of macroaggregates are more positive than those of the summer POC values, the latter probably being affected by the presence of allochthonous organic matter.

\section{Sedimentation of SPM}

The summer temporal fluctuations in particulate protein, water-soluble carbohydrate and lipid concentrations in surface and bottom layers, and those of sedimented particulate constituents, showed some dissimilarities. A likely explanation may be that the composition of rapidly sinking matter, such as zooplankton faecal pellets (Downs \& Lorenzen 1985, Altabet 1989) and the larger macroaggregates described above, differs from that of suspended POM, and that there is an intense degradation of smaller, slowly sinking particles accumulating at the pycnocline (Herndl 1989) in a summer density-stratified water column. These statements are illustrated by the compositional difference between suspended particulates and sedimental particles: the decrease amounted to ca $74 \%$ for lipids and 83 to $85 \%$ for water-soluble carbohydrates and pro- 
teins. A similar percentage (ca $80 \%$ ) of particulate amino acid loss during sedimentation was previously described for summer and winter periods in the water column of the Gulf of Trieste (Faganeli 1989).

The rapid sedimentation of macroaggregates in midAugust 1989 on the occasion of an abrupt wind disruption of the pycnocline was reflected in a higher sedimentation rate of total organic matter but a lower sedimentation rate of proteins, lipids and water-soluble carbohydrates. The protein content of sedimented matter was similar to that of macroaggregates, with lipids somewhat higher but water-soluble carbohydrates much lower, due to the degradation of reserve glucans and dissolution into the surrounding water (Ittekkot et al. 1982, Tanoue \& Handa 1987), and their use in phytoplankton respiration (Handa \& Yanagi 1969). More stable and water-insoluble structural (cell-wall) polysaccharides are thus the most important source of carbohydrates in sedimented matter and marine sediments. A more negative ${ }^{13} \mathrm{C}$ value of sedimented macroaggregates in July 1988 relative to that of the surface layer most likely indicates mixing with other plankters and POM, generally with more negative $\delta^{13} \mathrm{C}$ values (Faganeli et al. 1988), or selective degradation of more labile components, such as amino acids and carbohydrates (Wefer et al. 1982). It is well known that the $\delta^{13} \mathrm{C}$ values of planktonic lipids are 8 to $10 \%$ more negative than those of more degradable proteins and carbohydrates (Degens et al. 1968). On the other hand, only $4 \%$ more negative $\delta{ }^{13} \mathrm{C}$ values were found after anaerobic degradation of algal organic matter (Spiker \& Hatcher 1984). Moreover, practically no fractionation was observed under oxic degradation of planktonic material (Gearing et al. 1984). The lower $\mathrm{C} / \mathrm{N}$ ratio of sedimented macroaggregates also suggests intense bacterial degradation, or adsorption of dissolved nitrogen compounds.

A comparison of the composition of sedimented POM in the Gulf of Trieste with that of hydrologically and biologically different marine environments seems interesting, bearing in mind the different analytical methods used. Assuming a POM:POC ratio of 2 (Riley 1970), the percentage of protein in sedimented POC was similar to that in the Kiel Bight (up to $15 \%$; Liebezeit et al. 1985), but lower than that observed in some deep-sea environments, e.g. the Panama basin (15 to $35 \%$; Lee et al. 1983), offshore of Peru, and the equatorial Atlantic (20 to $30 \%$; Liebezeit \& von Bodungen 1987). The total carbohydrate content of sedimented POM in the Gulf of Trieste was higher than in Dabob Bay (9\%; Hedges et al. 1988), ocean environments off Antarctica (10 to $15 \%$; Liebezeit \& von Bodungen 1987), and the northern North Pacific (8 to $10 \%$; Tanoue $\&$ Handa 1987 ), but the lipid content was lower, i.e. 5 to $10 \%$ of sedimented POM in the Panama basin (Lee et al. 1983). The striking characteristic of sedimented as well as suspended POM in the Gulf of Trieste appears to be a relatively high carbohydrate content, probably in part land-derived (of vascular plant origin), although cellulose and its monomer glucose are highly degradable in the water column (Hedges et al. 1988).

The sum of analyzed chemical constituents represented only a minor fraction of the sedimented, as well as summer suspended, POM in the Gulf of Trieste, in accordance with various reports from different marine environments, e.g. Dabob Bay, USA (Hedges et al. 1988), the Sargasso Sea (Ittekkot et al. 1984) and the South Atlantic (Wefer et al. 1982). The bulk of sedimented and suspended POM in the Gulf is thus probably present in other chemical forms, such as humates (Degens 1970), hydrocarbons (Bates et al. 1984), lignin (Hedges et al. 1988) and probably other land-derived organic matter, indicated by more negative summer $\delta{ }^{13} \mathrm{C}$-POC values in the Gulf. Some, probably a minor, part of the difference could arise from the not completely specific analytical methods or standards applied. Thus, protein determination in the $\mathrm{NaOH}$ extracts (Rausch 1981) from cultured phytoplankters gave 2- to 3 -fold higher yields than in aqueous extracts (Faganeli et al. 1989). However, a comparison of our protein measurements with published amino acid sedimentation data (Faganeli 1989) revealed very similar rates, suggesting that the great majority of sedimented amino acids were bound to proteins.

The major fraction of the total sedimented matter in summer was inorganic, with a composition similar to that of the surficial sediment in this area of the Gulf of Trieste (Ogorelec et al. 1991). The presence of the authigenic mineral pyrite, occurring regularly in the surficial sediment a few millimeters below the sediment-water interface, in the sedimented matter in September 1989 is an indication of resuspension of bottom sediment. Following the method of Gasith (1975), which calculates the degree of resuspension from the known composition (pyrite content) of sedimented particulate matter and surficial marine sediment (Ogorelec et al. 1991), it was found that resuspension accounted for ca $2 / 3$ or sedimented matter in that period.

Acknowledgement. The authors express their appreciation to Mrs Annelie Skoog and Dr Knut Lindquist from the Chalmers University of Technology, Göteborg (Sweden), for supplying the samples of marine humic and fulvic acids and ligninsulphonate.

\section{LITERATURE CITED}

Alldredge, A. L. (1979). The chemical composition of macroscopic aggregates in two neritic seas. Limnol. Oceanogr. 24: $855-866$ 
Alldredge, A. L., Gotschalk, C. C. (1989). Direct observations of the mass flocculation of diatom blooms: characteristics, settling velocities and formation of diatom aggregates. Deep Sea Res. 36: 159-171

Alldredge, A. L., Silver, M. W (1988). Characteristics, dynamics and significance of marine snow. Prog. Oceanogr. 20: 41-82

Altabet, M. A. (1989). A time-series study of the vertical structure of nitrogen and particle dynamics in the Sargasso Sea. Limnol. Oceanogr. 34: 1185-1201

Bates, T S., Hamilton, S. E., Cline, J. D. (1984). Vertical transport and sedimentation of hydrocarbons in the central main basin of Puget Sound, Washington, Environ. Sci. Technol. 18: 299-305

Billett, D. S. M., Lampitt, R. S., Rice, A. L., Mantoura, R. F. C. (1983). Seasonal sedimentation of phytoplankton to the deep-sea benthos. Nature, Lond. 302: 520-522

Blomqvist, S., Kofoed, D. (1981). Sediment trapping - a sub aquatic in situ experiment. Limnol. Oceanogr. 26: 585-590

Brambati. A. (1988). Il fenomeno del 'mare sporco' nell Adriatico. Consiglio Nazionale delle Ricerche, Trieste-Roma

Cowie, G. L., Hedges, J. I. (1984). Carbohydrate sources in a coastal marine environment. Geochim. cosmochim. Acta 48: 2075-2087

Degens, E. T (1970). Molecular nature of nitrogenous compounds in sea water and recent marine sediments. In: Hood. D. W (ed.) Organic matter in natural waters. Occ Publs Inst. mar. Sci. Univ. Alaska Coll. 1. 77-106

Degens, E. T., Behrendt, M., Gotthardt, B., Reppmann, E (1968). Metabolic fractionation of carbon isotopes in marine plankton. II. Data on samples collected off the coasts of Peru and Ecuador. Deep Sea Res. 15: 11-20

Degens, E. T., Ittekkot, V. (1985). The carbon cycle - tracking the path of organic particles from sea to sediment. In: Brooks, J., Fleet, A. (eds.) Special conference of marine petroleum source Rocks. Geol. Soc. London. Blackwell, Oxford

Degobbis, D. (1989). Increased eutrophication of the Northern Adriatic sea. Mar Pollut. Bull. 20: 452-457

Domagalski. J. L., Orem, W. H., Eugster, H. P. (1989). Organic geochemistry and brine composition in Great Salt, Moro, and Walker Lakes. Geochim. cosmochim. Acta 53: $2857-2872$

Downs, J. N., Lorenzen, C. J. (1985). Carbon:pheopigment ratios of zooplankton fecal pellets as an index of herbivorous feeding. Limnol. Oceanogr 30: 1024-1036

Dubois, M., Gilles, K. A., Hamilton, J. K., Rebers, P. A., Smith, F. (1956). Colorimetric method for determination of sugars and related substances. Analyt. Chem. 28: 350-356

Faganeli, J. (1989). Sedimentation of particulate nitrogen and amino acids in shallow coastal waters (Gulf of Trieste, Northern Adriratic). Mar Chem. 26: 67-80

Faganeli, J., Malej, A., Pezdič, J., Malačič, V (1988). C:N:P ratios and stable $\mathrm{C}$ isotopic ratios as indicators of sources of organic matter in the Gulf of Trieste (Northern Adriatic). Oceanol. Acta 11.377-382

Faganeli, J., Pezdič, J., Fanuko, N. (1989). Chemical and isotopic composition of some phytoplankton species. Bioloski Vestnik 37: 9-18

Faganeli. J, Planinc, R., Pezdič, J., Smodiš, B.. Stegnar, P., Ogorelec, B. (1991). Marine geology of the Gulf of Trieste (northern Adnatic). B. Geochemical properties. Mar. Geol. 99: 93-108

Fanuko, N., Turk, V (1990). The oceanologic properties of the seawater in the Gulf of Trieste before and during the 'mare sporco' phenomenon (summer 1988). Boll. Oceanol. teor. appl. 8: 3-11
Fowler, S. W., Knauer, G. A. (1986). Role of large particles in the transport of elements and organic compounds through the oceanic water column. Prog. Oceanogr. 16: 147-194

Fry, B., Sherr, E. B. (1984). $\delta^{13} \mathrm{C}$ measurements as indicators of carbon flow in marine and freshwater ecosystems. Contr mar. Sci. 27: 13-47

Gasith, A. (1975). Tripton sedimentation in eutrophic lakes sample correction for the resuspended matter. Verh. int Verein. Limnol. 19: 116-122

Gearing, J. N., Gearing, P. J., Rudnick, D. T., Requejo, A. G., Hutchtins, M. J. (1984). Isotopic variability of organic carbon in a phytoplankton-based, temperature estuary. Geochim. cosmochim. Acta 42: 1089-1098

Handa, N., Yanagi, K. (1969). Studies on water-extractable carbohydrates of particulate matter from the northwest Pacific Ocean. Mar. Biol. 4: 197-207

Haug, A., Myklestad, S. (1976). Polysaccharides of marine diatoms with special reference to Chaetoceros species. Mar. Biol. 34: 217-222

Haug, A., Myklestad, S., Sakshaug, E. (1973). Studies on the phytoplankton ecology of the Trondheimstjord. I. The chemical composition of phytoplankton populations. J. exp. mar Biol. Ecol. 11: 15-26

Hecky, R. E., Mopper, K., Kilham, P., Degens, E. T (1973). The amino acid and sugar composition of diatom cell-walls. Mar. Biol. 19: 323-331

Hedges, J. I., Clark, W. A., Cowie, G. L. (1988). Organic matter sources to the water column and surficial sediments of a marine bay. Limnol. Oceanogr. 33: 1116-1136

Herndl, G. J. (1989). Diel and spatial variations in bacterial density in a stratified water column of the Gulf of Trieste. Prog. Oceanogr. 21 139-146

Herndl, G. J., Peduzzi, P. (1988). The ecology of amorphous aggregations (marine snow) in the Northern Adriatic sea. P.S.Z.N. I: Mar Ecol. 9: 79-90

Heusner, S., Monaco, A., Fowler, S. W. (1987). Characterization and vertical transport of settling biogenic particles in the northwestern Mediterranean. Mitt. geol.-paläont. Inst. Univ. Hamburg (SCOPE/UNEP Sonderb.) 62: 127-147

Ittekkot, V., Degens, E. T., Brockmann, U. (1982). Monosaccharide composition of acid-hydrolyzable carbohydrates in particulate matter during a plankton bloom. Limnol. Oceanogr. 27: 770-776

Ittekkot, V., Deuser, W G., Degens, E. T (1984). Seasonality in the fluxes of sugars, amino acids, and amino sugars to the deep ocean: Sargasso Sea. Deep Sea Res. 31: $1057-1069$

Kochert, G. (1978). Protein determination by dye binding. In: Hellebust, J. A., Cragie, J. C. (eds.) Handbook of phycological methods: physiological and biochemical methods. Cambridge University Press, London, p. 92-93

Lee, C., Wakeham, S. (1989). Organic matter in seawater: bıogeochemical processes. In: Riley, J. P. (ed.) Chemical oceanography, Vol. IX. Academic Press, London, p. 1-51

Lee, C., Wakeham, S. G., Farrington, J. W (1983). Variatıons in the composition of particulate organic matter in a time series sediment trap. Mar. Chem. 13: 181-194

Luebezeit, G. (1987). Particulate carbohydrate fluxes in the Bransfield strait and the Drake passage. Mar. Chem. 20: $25.5-264$

Liebezeit, G., Schumann, M., Bohde, F. (1985). Residual amino acid fluxes in Kiel Bight - February to June 1980. Mar. Ecol. Prog. Ser. 27. 203-207

Llebezeit, G., von Bodungen, B. (1987). Blogenic fluxes in the Bransfield strait: planktonic versus macroalgal sources. Mar. Ecol. Prog. Ser 36: 23-32

Mayer, L. M., Schick, L. L., Setchell, F. W. (1986). Measure- 
ment of protein in nearshore marine sediments. Mar. Ecol. Prog. Ser. 30: 159-165

Mopper, K. (1977). Sugars and uronic acids in sediment and water from the Black Sea and North Sea with emphasis on analytical techniques. Mar. Chem. 5: 585-603

Ogorelec, B., Mišič, M. Faganeli, J. (1991). Marine geology of the Gulf of Trieste, A - Sedimentological properties. Mar. Geol. 99: 79-91

Packard, T T., Dortch, Q. (1975). Particulate protein-nitrogen in North Atlantic surface waters. Mar Biol. 33: 347-354

Percival, E., Rahman, M. A., Weigel, H. (1980). Chemistry of polysaccharides of diatom Coscinodiscus nobilus. Phytochem. 19: 809-811

Rausch. T. (1981). The estimation of micro-algal protein content and its meaning to the evaluation of algal biomass. I. Comparison of methods for extracting protein. Hydrobiologia 78: 237-251

Riley, G. A. (1970). Particulate organic matter in sea water. Adv. mar. Biol. 8: 1-118

Sackett, W. M. (1978). Suspended matter in seawater. In: Riley, J. P., Chester, R. (eds.) Chemical oceanography, Vol. 7 Academic Press, London, p. 127-169

Setchell, F. W. (1981). Particulate protein measurement in oceanographic samples by dye binding. Mar. Chem. 10: 301-313

Small, L. F., Knauer, G. A., Tuel, M. D. (1987). The role of sinking fecal pellets in stratified euphotic zones. Deep Sea Res. 34: 1705-1712

This article was submitted to the editor
Smetacek, V. (1985). Role of sinking in diatom life-history cycles: ecological, evolutionary and geological significance. Mar. Biol. 84: 239-251

Spiker, E. C., Hatcher, P. G. (1984). Carbon isotope fractionation of sapropelic organic matter during early diagenesis Org. Geochem. 5: 283-290

Stachowitsch, M., Fanuko, N., Richter, M. (1990). Mucus aggregates in the Adriatic Sea: an overview of stages and occurrences. P.S.Z.N. I: Mar. Ecol. 11: 327-350

Tanoue, E., Handa, N. (1987). Monosaccharide composition of marine particles and sediments from the Bering Sea and northern North Pacific. Oceanol. Acta 10: 91-99

Toth, D. J., Lerman, A. (1977). Organic matter reactivity and sedimentation rates in the ocean. Am. J. Sci. 277: 465-485

Turner, I. T., Ferrante, I. G. (1979). Zooplankton faecal pellets in aquatic ecosystems. BioSci. 29:670-677

Wakeham, S. G., Lee, C. (1989). Organic geochemistry of particulate matter in the ocean: the role of particles in oceanic sedimentary cycles. Org. Geochem. 14: 83-96

Wefer, G., Suess, E., Balzer, W., Liebezeit, G., Müller, P. J., Ungerer, C. A., Zenk, W. (1982). Fluxes of biogenic compounds from sediment trap deployment in circumpolar waters of Drake passage. Nature, Lond. 229; 145-147

Zöllner, N., Kirsch, K. (1962). Über die quantitative Bestimmung von Lipoiden (Mikromethode) mittels der vielen Lipoiden (allen bekannten Plasma Lipoiden) gemeinsam Sulfo-Phospho-Vanillin Reaktion. Verh. dt. Ges. exp. Med. 135: $545-561$

Manuscript first received: November 28, 1990

Revised version accepted: August 27, 1991 